\title{
An Examination of the Employment Recovery in the United States in the Wake of the COVID-19 Pandemic
}

\author{
David C. Wyld
}

\section{ABSTRACT}

\begin{abstract}
The "shock" of the onset of the COVID-19 pandemic set about wholesale changes across American life, impacting the way we socialized, shopped, and yes, worked. There were significant disruptions across the business landscape in the United States, accompanied by significant job losses, starting in March 2020. In this article, we examine the size and scope of the changes in employment that took place in the U.S. at the start of the COVID-19 pandemic and during the recovery period up through April 2021. Utilizing official government data from the Bureau of Labor Statistics, the author examines how the pandemic caused both widespread job losses and record-setting levels of unemployment but had differential effects across a variety of industries. Then, the author looks at the recovery period, examining the recovery in employment has been unequally distributed across the United States, with differentiations between both urban and rural areas and between metropolitan areas across the county. The article concludes with a look at what this means for the future of work and for management moving forward - hopefully - into the post-pandemic period.
\end{abstract}

Keywords: COVID-19, economics, employment, jobs, management, unemployment.

\section{INTRODUCTION}

Unanticipated. Unprecedented. Unbelievable. Unfathomable. There were so very many adjectives applied to the very real economic fallout that occurred in the wake of the onset of the global coronavirus pandemic early in 2020 . COVID-19 has undoubtedly exacted a terrible human toll in terms of sickness and death, with to date (as of June 2021), over 33 million cases and over 600,000 deaths in the United States [1] and globally, over 178 million cases and approximately 3.9 million deaths [2]. And as horrible as the confirmed level of the pandemic has been, public health researchers estimate that the true case counts and deaths caused by the coronavirus may be multiples of the "official" numbers, both in the United States and even more so in countries around the world [3]. And so, while there may be scientific debate over just how bad the medical side of the coronavirus has been and may continue to be for some time, even in spite of rising vaccination numbers and hopes for "control" over the novel disease and a return to "normal" [4], the toll on businesses and jobs, especially in the United States, has been far easier to track.

And so, in the present research, the author will assess perhaps the most important question in the minds of business executives, government policy makers, and yes, average workers in the U.S. today: Where we have been and where we are going in terms of the COVID-19's impact on jobs in the United States. We will start with a look at the unprecedented "shock" to the economy that took place in early 2020 when the U.S. shutdown except for all but "essential" services (health care, plus some retail, government, etc.). Then, we will look at the recovery that has taken place one year from the onset of the pandemic, comparing employment numbers from April 2020 (the height of job losses) to April 2021. We will see that the employment picture is indeed muddled and that job recoveries have been unequal across America. The author will conclude by discussing the findings and implications for companies, for public policy, and for workers going forward into what will hopefully - be the post-pandemic period.

\section{MeTHODOLOGY}

The present research makes use of official United States government data on employment compiled by the Bureau of Labor Statistics (BLS), a unit within the Department of Labor. It is the primary source of economic data in regard to labor in the U.S. In this study, the author will use data on both jobs and unemployment compiled by the BLS during the period under review, from April 2020 to April 2021 [5].

\section{FINDINGS}

\section{A. The Fall}

The economy suffered a sudden shock when the full impact of the coronavirus hit the United States in March 2020. As one economic analyst aptly put it, while most past economic crises were like a prolonged illness, COVID-19's impact on the economy was like a massive "heart attack," causing instant disruptions to businesses and to employment [6]. 
Overnight, companies both large and small alike that had been operating successfully were thrown into crises - and in many cases bankruptcy - across large swaths of the economy. And despite aggressive action on the part of both federal and state governments in the U.S. to stem job losses and keep people employed, which was in the large part a "success" [7], the business and employment losses ushered in by the onset of the coronavirus pandemic were steep across the American landscape [8], and indeed, around the world [9].

How far and how fast did employment fall in the wake of the onset of the pandemic in the United States? According to data from the Bureau of Labor Statistics [10], from the midMarch 2020 period (when then-President Donald Trump issued the first of what became a series of 15-day orders encouraging Americans to radically adjust their behaviors to "slow the spread" of the coronavirus) [11] throughout the month of April 2020, the U.S. saw unprecedented levels of job losses, exceeding anything seen since employment data began being kept by the BLS in 1939 [12]!

Specifically, as can be seen in Fig. 1, over 21 million jobs were lost in just this six-week period, with over 800,00 people losing work in the latter half of March 2020 and approximately 20.5 million workers becoming unemployed in the following month! At the end of April 2020, overall employment - at just over 131 million - ironically was approximately at the point at which employment stood both at the turn of the century in 2000 and at the depth of the Great Recession in 2010.

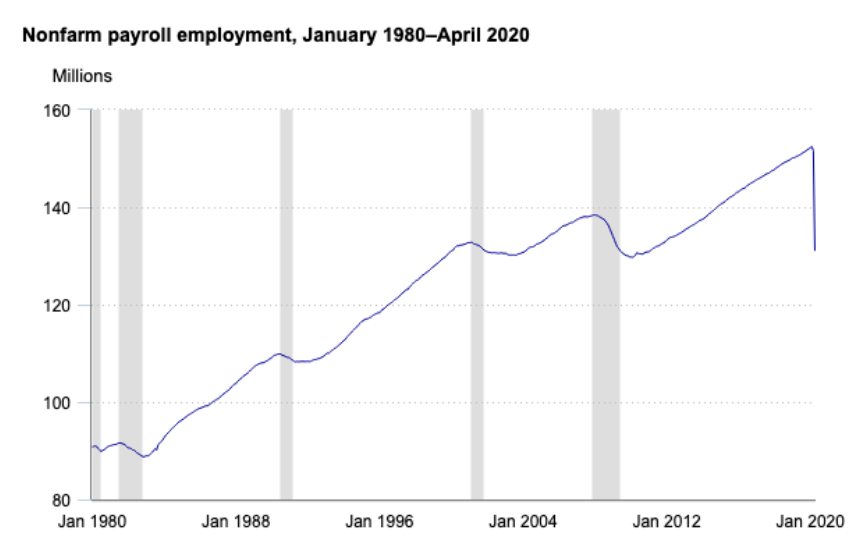

Fig. 1. Overall Employment in the United States, January 1980-April 2020. Source: U.S. Bureau of Labor Statistics, "Payroll employment down 20.5 million in April 2020,” May 12, 2020 (Used with Permission).

As can be seen in Fig. 2, the pandemic-induced job losses across specific sectors of the economy was, in a word, staggering. According to the BLS data, there were clearly job losses across the entire American economy. However, out of the 20 million jobs lost in April 2020, the majority of those people losing their employment were concentrated in just a few industries, including:

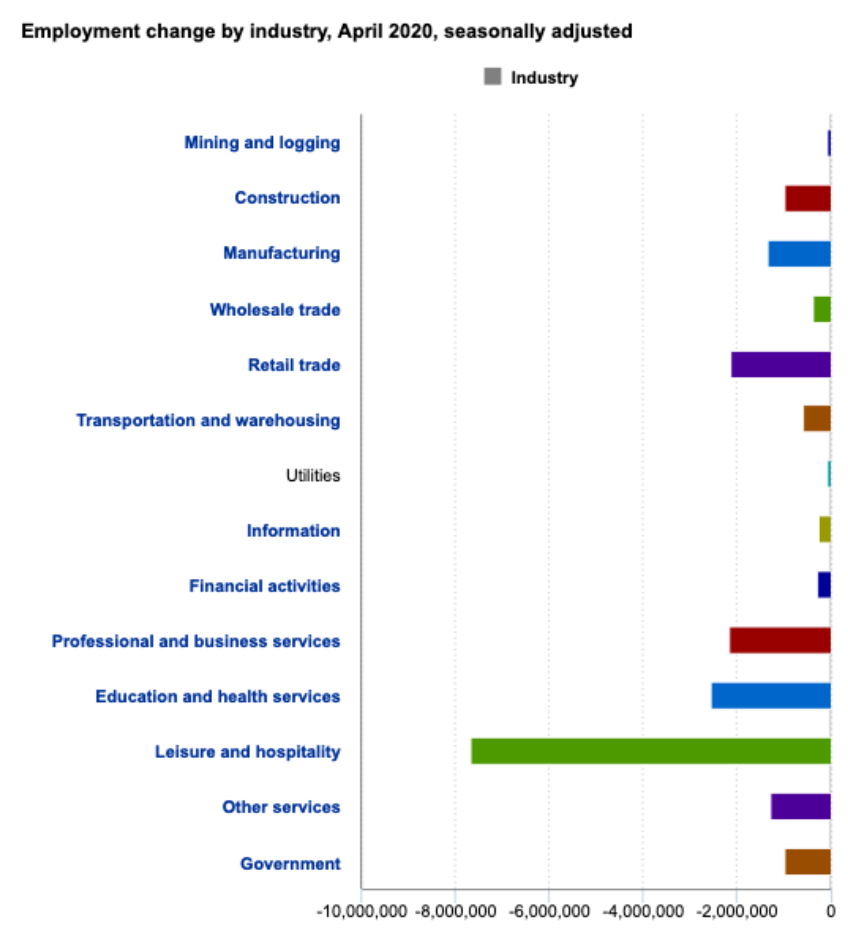

Fig. 2. Job Losses in Specific Sectors of the Economy, April 2020. Source: U.S. Bureau of Labor Statistics, "Payroll employment down 20.5 million in April 2020," May 12, 2020 (Used with Permission).

- Leisure and hospitality: Employment in this single area fell by 7.7 million, representing almost half $-47 \%$ - of the total number of jobs in these fields! Within this area of the economy, employment in restaurants, bars and other food service establishments fell by 5.5 million and in hotels and other accommodations by 839,000 . Employment also fell in the entertainment, the arts, and recreation areas by 1.3 million in this single month as well, as venues for live music, theatrical productions, and theme parks shut their doors.

- Education and health services: 2.5 million jobs were shed across both education and health services in this single month. Hundreds of thousands of teachers and support personnel lost their jobs - at least temporarily in April 2020 due to school closures coming in the wake of the onset of the COVID-19 pandemic. Also, despite all the focus on health care workers as "heroes" during the immediate stages of the pandemic, 1.4 million individuals employed in the health care sector - including those working in physician and/or dental offices and those performing what were deemed nonessential health services - actually lost their jobs in April 2020.

- Retail trade: 2.1 million jobs were lost in April 2020 alone in the retail sector of the economy. Particularly hard hit was those employed in clothing stores (740,000 jobs lost) and those working for new and used car dealers and auto parts stores (345,000 jobs lost). Additionally, due to weakened demand for consumerpackaged goods at the retail level, those employed at the wholesale level saw 363,000 job losses in that single month. Ironically, due to demand for "pandemic"-related items such as cleansers, hand sanitizers, and yes, toilet paper, the number of jobs at warehouse clubs (such as Sam's and Costco) and at 
"supercenter" stores operated by Walmart and Target actually increased by 93,000 in April 2020!

And so, in April 2020, according to the Bureau of Labor Statistics [12], the U.S. unemployment rate peaked at an alltime high of $14.7 \%$. In fact, the $14,7 \%$ April 2020 unemployment rate represented a jump of $10.3 \%$ over the prepandemic March 2020 rate of $4.4 \%$, meaning that the unemployment rate spiked by $234 \%$ in a single month! As can be seen in Fig. 3, the April $202014.7 \%$ unemployment rate was the highest such measure observed since the BLS began tracking this all-important economic - and personal - metric in 1948 ! The $14.7 \%$ rate far exceeded even the levels of unemployment seen in the U.S. during any prior recession, $9 / 11$, or any preceding event. And for all major subgroups whether categorized by gender, by age, by race - the April 2020 unemployment figure set an all-time record except for black unemployment, according to BLS analysts.

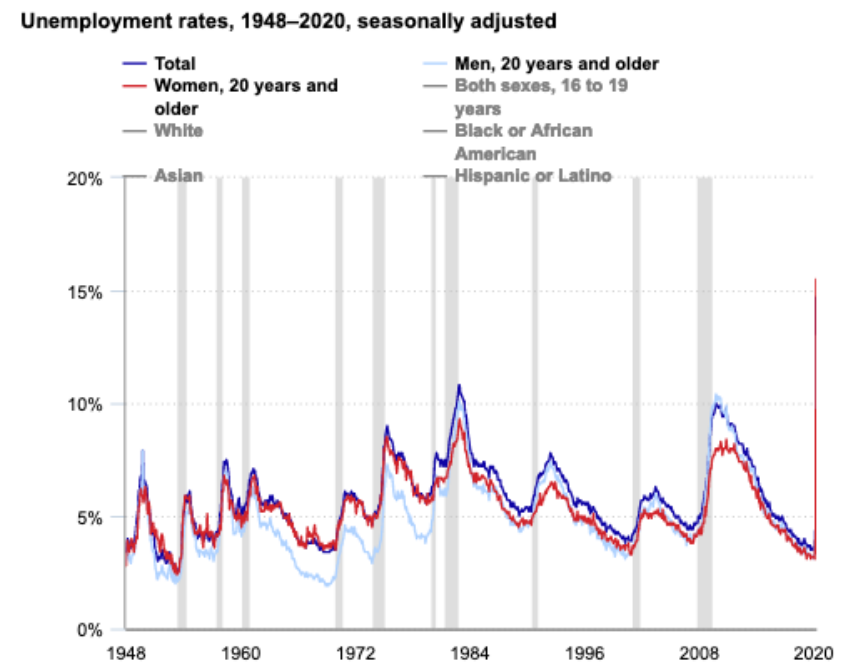

Fig. 3. The April 2020 U.S. Unemployment Rate in Historical Context. Source: U.S. Bureau of Labor Statistics, "Unemployment rate rises to record high 14.7 percent in April 2020," May 13, 2020 (Used with Permission).

\section{B. The Recovery}

Looking back on the early to mid-2020 period, it is rather remarkable just how fast the U.S. economy has rebounded. In fact, today, there is concern about too much demand in certain areas of the economy today (i.e., tourism, auto sales, real estate, etc.), causing worries over rising inflation, asset prices, and interest rates [13]. However, on the employment front, overall, there has been rather good news in terms of the way the American economy and businesses across the board have rebounded in the wake of the economic shock brought about by the COVID-19 pandemic. Yet, as we will see through an examination of the BLS data, the recovery in jobs has been unequal across the country and even across metropolitan areas of different sizes.

According to the Bureau of Labor Statistics [14], the "official" unemployment rate for April 2021 - a year after the economic "heart attack" of the pandemic hit the U.S. in earnest - stood at $6.1 \%$. This means that while the April 2021 rate was still significantly higher than the pre-pandemic $4.4 \%$ rate seen in March 2020, it is far, far below the $14.7 \%$ unemployment rate seen exactly a year earlier! While a broader measure of unemployment, including those workers who were working temporary jobs, those who shifted to parttime work but desire full-time employment and those who were out of the labor force and only marginally looking for employment, stood at $10.4 \%$ in April 2021, this must be seen in context. This is because the April 2021 figure of $10.4 \%$ was half that of the $22.9 \%$ figure for this broader measure seen a year earlier in April 2020! These trends over the past decade for the various ways of measuring unemployment can be seen in Fig. 4.

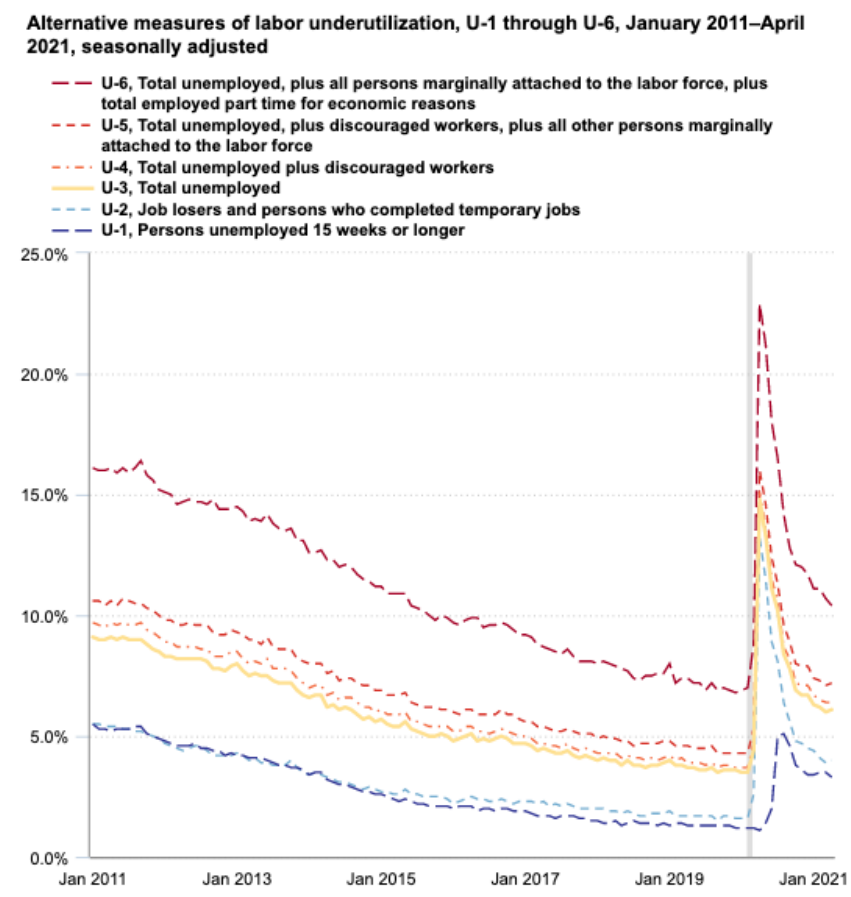

Fig. 4. Unemployment Measures in the United States, January 2011 - April 2021.

Source: U.S. Bureau of Labor Statistics, " $U-3$ was 6.1 percent, $U-6$ was 10.4 percent, in April 2021, ” May 12, 2021 (Used with Permission).

Not surprisingly, just as they suffered the biggest job losses due to the onset of the pandemic, BLS data shows the largest metropolitan areas in the country saw the largest job gains as the recovery from the pandemic took place [15]. As can be seen in Table I below, the metro areas in the United States with the largest population concentrations compiled the biggest gains in terms of the net number of jobs added in the 12-month period from April 2020 to April 2021. The New York metro area alone gained almost 1 million jobs, and ten metropolitan regions, including Los Angeles, Detroit, Dallas, Boston, Atlanta and more, saw the number of their citizens employed there rise by over 200,000 in that same time frame. In fact, the top 25 metro areas in terms of job gains saw employment rise by over 100,000 in their respective regions.

Yet, on a percentage basis, the growth in the employment picture really came from all across the country, and largely, outside of the biggest cities. As can be seen in Fig. 5, the BLS data reveals that far higher employment growth rates were found in metropolitan areas [5].

Specifically, as can be seen in Table II, the gains to be found in metropolitan areas with far smaller populations, such as Elkhart and Goshen, Indiana (up 52.8\% year-over-year) and Ocean City, New Jersey (up 46.7\%), far exceeded the percentage gains found in the most populous metro regions in 
the U.S. In fact, while the top 25 metro areas in terms of net employment gains (as seen in Table I) saw job growth averaging $10.9 \%$, the top 25 metro areas in terms of percentage job growth averaged $24.2 \%$ in their overall employment, a growth rate more than double that of their largely larger, more heavily populated counterparts!

TABLE I: TOP 25 U.S. METROPOLITAN AREAS RANKED By LARGEST NET CHANGE IN EMPLOYMENT, APRIL 2021 VS. APRIL 2020

\begin{tabular}{|c|c|c|c|c|}
\hline Rank & Metropolitan Area & (A) & (B) & (C) \\
\hline 1 & $\begin{array}{c}\text { New York-Newark-Jersey } \\
\text { City, NY-NJ-PA }\end{array}$ & $9,012.20$ & 966.7 & 12 \\
\hline 2 & $\begin{array}{c}\text { Los Angeles-Long Beach- } \\
\text { Anaheim, CA }\end{array}$ & $5,691.30$ & 431.6 & 8.2 \\
\hline 3 & $\begin{array}{c}\text { Detroit-Warren-Dearborn, } \\
\text { MI }\end{array}$ & $1,884.40$ & 378.8 & 25.2 \\
\hline 4 & $\begin{array}{c}\text { Dallas-Fort Worth- } \\
\text { Arlington, TX }\end{array}$ & $3,740.20$ & 326.8 & 9.6 \\
\hline 5 & $\begin{array}{c}\text { Chicago-Naperville-Elgin, } \\
\text { IL-IN-WI }\end{array}$ & $4,402.60$ & 313.2 & 7.7 \\
\hline 6 & $\begin{array}{c}\text { Philadelphia-Camden- } \\
\text { Wilmington, PA-NJ-DE- } \\
\text { MD }\end{array}$ & $2,802.70$ & 308.7 & 12.4 \\
\hline 7 & $\begin{array}{c}\text { Boston-Cambridge- } \\
\text { Nashua, MA-NH NECTA }\end{array}$ & $2,611.00$ & 278 & 11.9 \\
\hline 8 & $\begin{array}{l}\text { Miami-Fort Lauderdale- } \\
\text { West Palm Beach, FL }\end{array}$ & $2,572.20$ & 255.8 & 11 \\
\hline 9 & $\begin{array}{c}\text { Atlanta-Sandy Springs- } \\
\text { Roswell, GA }\end{array}$ & $2,735.90$ & 249.5 & 10 \\
\hline 10 & $\begin{array}{c}\text { Washington-Arlington- } \\
\text { Alexandria, DC-VA-MD- } \\
\text { WV }\end{array}$ & $3,172.60$ & 207.5 & 7 \\
\hline 11 & $\begin{array}{l}\text { Houston-The Woodlands- } \\
\text { Sugar Land, TX }\end{array}$ & $3,018.90$ & 188.1 & 6.6 \\
\hline 12 & $\begin{array}{c}\text { Phoenix-Mesa-Scottsdale, } \\
\text { AZ }\end{array}$ & $2,173.10$ & 182.4 & 9.2 \\
\hline 13 & $\begin{array}{c}\text { San Francisco-Oakland- } \\
\text { Hayward, CA }\end{array}$ & $2,266.50$ & 161.1 & 7.7 \\
\hline 14 & $\begin{array}{l}\text { Minneapolis-St. Paul- } \\
\text { Bloomington, MN-WI }\end{array}$ & $1,890.50$ & 151.1 & 8.7 \\
\hline 15 & $\begin{array}{l}\text { Las Vegas-Henderson- } \\
\text { Paradise, NV }\end{array}$ & 929.7 & 150.3 & 19.3 \\
\hline 16 & $\begin{array}{c}\text { Riverside-San Bernardino- } \\
\text { Ontario, CA }\end{array}$ & $1,514.20$ & 146.3 & 10.7 \\
\hline 17 & Pittsburgh, PA & $1,111.70$ & 141.8 & 14.6 \\
\hline 18 & $\begin{array}{l}\text { Tampa-St. Petersburg- } \\
\text { Clearwater, FL }\end{array}$ & $1,379.30$ & 139.1 & 11.2 \\
\hline 19 & San Diego-Carlsbad, CA & $1,399.40$ & 132.2 & 10.4 \\
\hline 20 & $\begin{array}{l}\text { Denver-Aurora-Lakewood, } \\
\text { CO }\end{array}$ & $1,484.10$ & 129.6 & 9.6 \\
\hline 21 & $\begin{array}{c}\text { Seattle-Tacoma-Bellevue, } \\
\text { WA }\end{array}$ & $1,991.20$ & 123.6 & 6.6 \\
\hline 22 & $\begin{array}{l}\text { Baltimore-Columbia- } \\
\text { Towson, MD }\end{array}$ & $1,355.10$ & 121.2 & 9.8 \\
\hline 23 & Cincinnati, OH-KY-IN & $1,073.30$ & 120 & 12.6 \\
\hline 24 & Austin-Round Rock, TX & $1,125.00$ & 119.6 & 11.9 \\
\hline 25 & St. Louis, MO-IL & $1,346.70$ & 112.9 & 9.2 \\
\hline
\end{tabular}

(A): Total Metro Area Employment in April 2021 (thousands).

(B): 12 Month Net Change in Employment (thousands).

(C): 12 Month Net Change in Employment (\%).

Source Data: U.S. Bureau of Labor Statistics, "335 Metro Areas Had Overthe-Year Employment Increases in April 2021, ” June 10, 2021 (Used with Permission).

In terms of the flip side of the employment picture, unemployment, the Bureau of Labor Statistics data likewise reveals some interesting findings regarding the areas of the country where there are likely to be significant, long-term unemployment and underemployment. As can be seen in Fig. 6 , unemployment rates vary widely both across the country and even within states themselves. Take for instance states like Texas and Florida, which can be seen to have metro areas with both the highest and lowest levels of unemployment within their respective borders.

TABLE II: ToP 25 U.S. METROPOLITAN AREAS RANKED BY LARGEST PERCENTAGE GAINS IN EMPLOYMENT, APRIL 2021 VS. APRIL 2020

\begin{tabular}{|c|c|c|c|c|}
\hline Rank & Metropolitan Area & (A) & (B) & (C) \\
\hline 1 & Elkhart-Goshen, IN & 137.1 & 47.4 & 52.8 \\
\hline 2 & Ocean City, NJ & 42.4 & 13.5 & 46.7 \\
\hline 3 & Atlantic City-Hammonton, NJ & 117.6 & 28.2 & 31.5 \\
\hline 4 & Flint, MI & 130.1 & 30 & 30 \\
\hline 5 & Saginaw, MI & 80.5 & 16.5 & 25.8 \\
\hline 6 & East Stroudsburg, PA & 54.1 & 11.1 & 25.8 \\
\hline 7 & Barnstable Town, MA NECTA & 96.1 & 19.4 & 25.3 \\
\hline 8 & Detroit-Warren-Dearborn, MI & $1,884.40$ & 378.8 & 25.2 \\
\hline 9 & Gettysburg, PA & 33.5 & 6.6 & 24.5 \\
\hline 10 & $\begin{array}{c}\text { Myrtle Beach-Conway-North } \\
\text { Myrtle Beach, SC-NC }\end{array}$ & 168.8 & 31.7 & 23.1 \\
\hline 11 & $\begin{array}{l}\text { Norwich-New London- } \\
\text { Westerly, CT-RI NECTA }\end{array}$ & 113 & 20.6 & 22.3 \\
\hline 12 & Salisbury, MD-DE & 157.8 & 28.1 & 21.7 \\
\hline 13 & Muskegon, MI & 57.5 & 10.2 & 21.6 \\
\hline 14 & New Bedford, MA NECTA & 62.9 & 11 & 21.2 \\
\hline 15 & Bay City, MI & 32.8 & 5.5 & 20.1 \\
\hline 16 & Glens Falls, NY & 50.7 & 8.3 & 19.6 \\
\hline 17 & York-Hanover, PA & 180.6 & 29.4 & 19.4 \\
\hline 18 & Fond du Lac, WI & 47.4 & 7.7 & 19.4 \\
\hline 19 & $\begin{array}{c}\text { Las Vegas-Henderson-Paradise, } \\
\text { NV }\end{array}$ & 929.7 & 150.3 & 19.3 \\
\hline 20 & Grand Rapids-Wyoming, MI & 529.6 & 83.8 & 18.8 \\
\hline 21 & $\begin{array}{c}\text { Buffalo-Cheektowaga-Niagara } \\
\text { Falls, NY }\end{array}$ & 525.3 & 82.7 & 18.7 \\
\hline 22 & $\begin{array}{l}\text { Naples-Immokalee-Marco } \\
\text { Island, FL }\end{array}$ & 156 & 24.2 & 18.4 \\
\hline 23 & $\begin{array}{l}\text { Hilton Head Island-Bluffton- } \\
\text { Beaufort, SC }\end{array}$ & 82.7 & 12.7 & 18.1 \\
\hline 24 & Mansfield, $\mathrm{OH}$ & 49.4 & 7.5 & 17.9 \\
\hline 25 & Portsmouth, NH-ME NECTA & 90.2 & 13.6 & 17.8 \\
\hline
\end{tabular}

Guide to Table:

(A): Total Metro Area Employment in April 2021 (thousands).

(B): 12 Month Net Change in Employment (thousands).

(C): 12 Month Net Change in Employment (\%).

Source Data: U.S. Bureau of Labor Statistics, "335 Metro Areas Had Overthe-Year Employment Increases in April 2021, ” June 10, 2021 (Used with Permission).

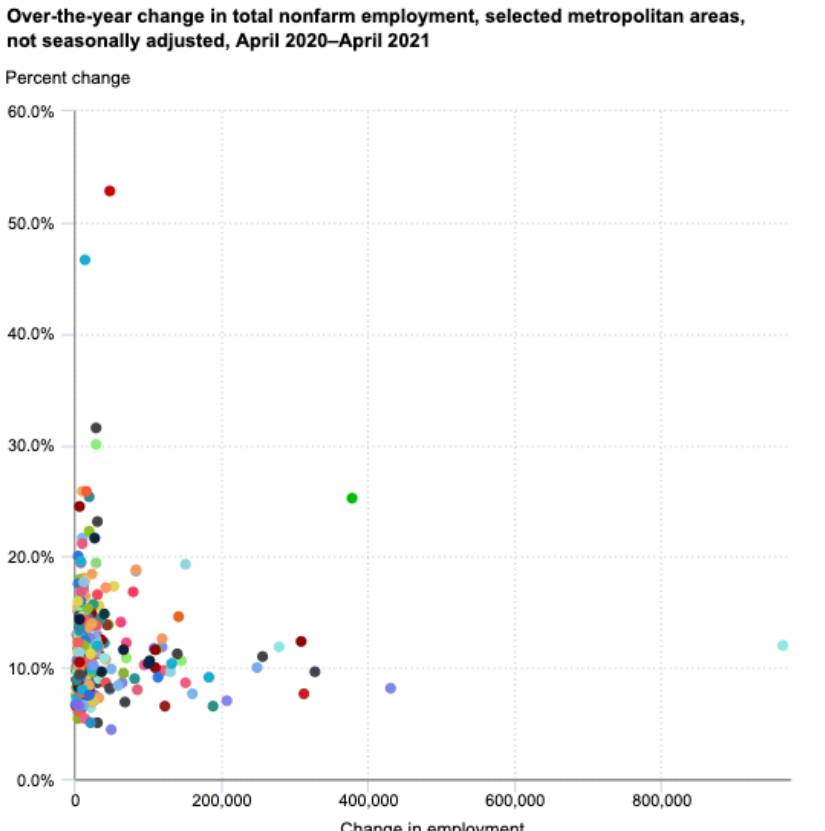

Fig. 5. Unemployment Percentage Change in Total Nonfarm Employment in Select Metropolitan Areas in the U.S., April 2021 vs. April 2020 Source: U.S. Bureau of Labor Statistics, "335 Metro Areas Had Over-theYear Employment Increases in April 2021, ” June 10, 2021 (Used with Permission). 
Metropolitan area unemployment rates, April 2021, not seasonally adjusted

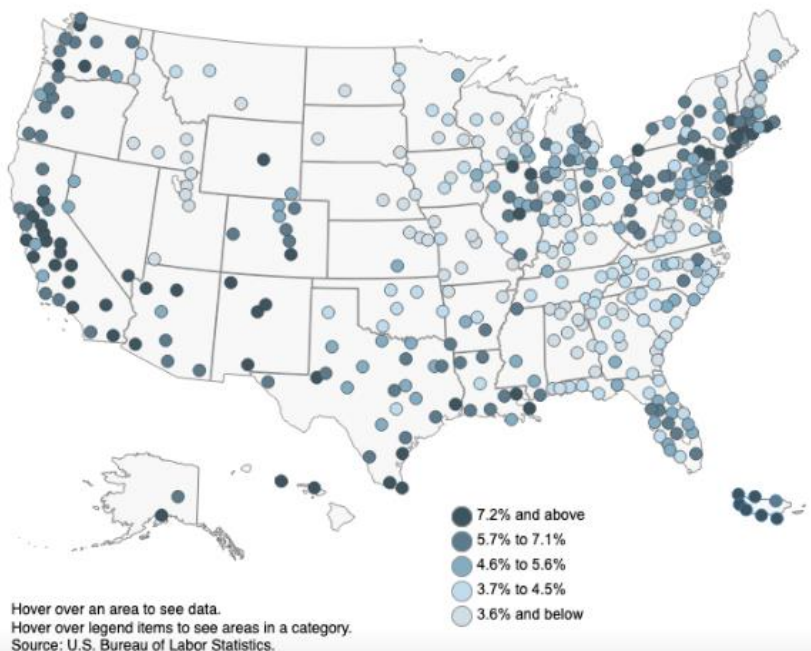

Fig. 6. Unemployment by Metro Areas in the U.S., April 2021. Source: U.S. Bureau of Labor Statistics, "335 Metro Areas Had Over-theYear Employment Increases in April 2021, ” June 10, 2021 (Used with Permission).

Indeed, there appears to be some very significant regional disparities in regard to unemployment revealed in the Bureau of Labor Statistics data. Contrast the rankings of the metro areas with the highest rates of unemployment (shown in Table III) with those with the lowest levels of unemployment (shown in Table IV).

TABLE III: U.S. METROPOLITAN AREAS WITH THE HIGHEST RATES OF UNEMPLOYMENT, APRIL 2021

\begin{tabular}{|c|c|c|c|c|}
\hline Rank & Metropolitan Area & State & (A) & (B) \\
\hline 1 & El Centro, CA & California & 28.6 & 16.1 \\
\hline 2 & Yuma, AZ & Arizona & 25 & 13.1 \\
\hline 3 & Kahului-Wailuku-Lahaina, HI & Hawaii & 32.9 & 11.5 \\
\hline 4 & Visalia-Porterville, CA & California & 18.6 & 11 \\
\hline 5 & Atlantic City-Hammonton, NJ & New Jersey & 34.4 & 11 \\
\hline 6 & Merced, CA & California & 18.5 & 10.9 \\
\hline 7 & Bakersfield, CA & California & 18.6 & 10.7 \\
\hline 8 & McAllen-Edinburg-Mission, TX & Texas & 17.5 & 10.3 \\
\hline 9 & Hanford-Corcoran, CA & California & 16.9 & 10.2 \\
\hline 10 & Ocean City, NJ & New Jersey & 27.9 & 10 \\
\hline 11 & $\begin{array}{c}\text { Los Angeles-Long Beach- } \\
\text { Anaheim, CA }\end{array}$ & California & 17.3 & 9.9 \\
\hline 12 & Beaumont-Port Arthur, TX & Texas & 17.4 & 9.9 \\
\hline 13 & Odessa, TX & Texas & 13.5 & 9.9 \\
\hline 14 & Rockford, IL & Illinois & 22.5 & 9.7 \\
\hline 15 & Fresno, CA & California & 17.1 & 9.6 \\
\hline 16 & Madera, CA & California & 17.4 & 9.5 \\
\hline 17 & Yuba City, CA & California & 17.2 & 9.4 \\
\hline 18 & Waterbury, CT & Connecticut & 9.4 & 9.1 \\
\hline 19 & Brownsville-Harlingen, TX & Texas & 16.2 & 9.1 \\
\hline 20 & Stockton-Lodi, CA & California & 17.9 & 9 \\
\hline 21 & $\begin{array}{c}\text { Las Vegas-Henderson-Paradise, } \\
\text { NV }\end{array}$ & Nevada & 33.3 & 9 \\
\hline 22 & Farmington, NM & $\begin{array}{l}\text { New } \\
\text { Mexico }\end{array}$ & 11.1 & 8.9 \\
\hline 23 & Modesto, CA & California & 17.2 & 8.6 \\
\hline 24 & Salinas, CA & California & 19.1 & 8.6 \\
\hline 25 & Pueblo, CO & Colorado & 11.3 & 8.6 \\
\hline
\end{tabular}

(A): April 2020 Unemployment Rate (\%).

(B): April 2021 Unemployment Rate (\%).

Source Data: U.S. Bureau of Labor Statistics, "335 Metro Areas Had Overthe-Year Employment Increases in April 2021, ” June 10, 2021 (Used with Permission).
TABLE IV: U.S. METROPOLITAN AREAS WITH THE LOWEST RATES OF UNEMPLOYMENT, APRIL 2021

\begin{tabular}{|c|c|c|c|c|}
\hline Rank & Metropolitan Area & State & (A) & (B) \\
\hline 1 & Logan, UT & Utah & 6 & 2 \\
\hline 2 & Huntsville, AL & Alabama & 10 & 2.2 \\
\hline 3 & Lincoln, NE & Nebraska & 8 & 2.2 \\
\hline 4 & Auburn-Opelika, AL & Alabama & 12.3 & 2.3 \\
\hline 5 & Decatur, AL & Alabama & 10.2 & 2.3 \\
\hline 6 & Provo-Orem, UT & Utah & 7.7 & 2.4 \\
\hline 7 & $\begin{array}{l}\text { Daphne-Fairhope- } \\
\text { Foley, AL }\end{array}$ & Alabama & 14.5 & 2.5 \\
\hline 8 & Gainesville, FL & Florida & 10.4 & 2.5 \\
\hline 9 & Ames, IA & Iowa & 8.1 & 2.5 \\
\hline 10 & Grand Island, NE & Nebraska & 8.9 & 2.5 \\
\hline 11 & $\begin{array}{l}\text { Burlington-South } \\
\text { Burlington, VT }\end{array}$ & Vermont & 12.8 & 2.5 \\
\hline 12 & Manhattan, KS & Kansas & 8.8 & 2.6 \\
\hline 13 & Columbia, $\mathrm{MO}$ & Missouri & 8.5 & 2.6 \\
\hline 14 & Sioux Falls, SD & South Dakota & 9 & 2.6 \\
\hline 15 & Ogden-Clearfield, UT & Utah & 9.7 & 2.6 \\
\hline 16 & $\begin{array}{c}\text { Birmingham-Hoover, } \\
\text { AL }\end{array}$ & Alabama & 11.5 & 2.7 \\
\hline 17 & Idaho Falls, ID & Idaho & 8 & 2.7 \\
\hline 18 & Jefferson City, MO & Missouri & 8 & 2.7 \\
\hline 19 & Manchester, NH & New Hampshire & 16.2 & 2.7 \\
\hline 20 & Dothan, AL & Alabama & 9.6 & 2.8 \\
\hline 21 & $\begin{array}{c}\text { Florence-Muscle } \\
\text { Shoals, AL }\end{array}$ & Alabama & 14.6 & 2.9 \\
\hline 22 & $\begin{array}{c}\text { Fayetteville- } \\
\text { Springdale-Rogers, } \\
\text { AR }\end{array}$ & Arkansas & 7.6 & 2.9 \\
\hline 23 & $\begin{array}{l}\text { Omaha-Council } \\
\text { Bluffs, NE }\end{array}$ & Nebraska & 8.7 & 2.9 \\
\hline 24 & Dover-Durham, NH & New Hampshire & 14.3 & 2.9 \\
\hline 25 & Portsmouth, NH & New Hampshire & 14.1 & 2.9 \\
\hline
\end{tabular}

(A): April 2020 Unemployment Rate (\%).

(B): April 2021 Unemployment Rate (\%).

Source Data: U.S. Bureau of Labor Statistics, “335 Metro Areas Had Overthe-Year Employment Increases in April 2021, ” June 10, 2021 (Used with Permission).

As the BLS data reveals, there were across the board declines in all the metropolitan areas having the highest and lowest April 2021 unemployment rates from the peak that occurred in April 2020 with the pandemic-caused job losses. However, as can be seen in Tables III and IV, there were significant differences to be found in terms of how different areas of the country were impacted by unemployment problems. For instance, looking at Table III, California (the most populated state in the country) dominated that list, having 12 of the top 25 metropolitan areas with the worst unemployment presently (as of April 2021), with Texas (the second largest state in terms of population) coming in second in that ranking as well with 4 metro areas. By way of contrast, in looking at Table IV, the list is composed of mostly small metropolitan areas in smaller population states, such as Alabama (7 of the best metro areas for unemployment) and Nebraska, New Hampshire, and Utah, which each had 3 metro areas on the list. In fact, the Gainesville, Florida metro area, having the 8th lowest unemployment rate in the country, was located in a state that ranked in the top ten most populous U.S. states (White, 2021). Overall, the highest unemployment rate was in the El Centro, California metropolitan area at $16.1 \%$, while the lowest was in the Logan, Utah metro area, where unemployment stood at just $2 \%$. 


\section{CONCLUSION}

The past 18 months have been unprecedented, both in the public health arena and in economic terms. There has been great pain and upheaval across society due to the COVID-19 pandemic, and the effects of the coronavirus experience will linger far longer than the virus itself. In terms of business, we have seen companies and workers have to adapt to a very changed set of circumstances, finding new ways to do almost everything in response to the very real dangers posed by the coronavirus. But perhaps the most important long-term impact of COVID-19 on businesses will be the fact that the pandemic experience has very likely changed the employment picture - and the employment equation - longterm. COVID-19 has accelerated trends that were already taking shape across the economy and society that are fastchanging the way workers look at their relationships with their employers [17]. And at present, the whole notion of "work" and the grand bargain that exists between employers and employees is changing - and changing fast.

The numbers reported in this study certainly show that the jobs recovery has been faster than many experts anticipated. However, what we are seeing at present in terms of the worker shortage in the American economy is a rebalancing of the employment equation. In short, businesses will need to adapt to the fact that a greater percentage of the adult American population is not "working" in traditional jobs due to the fact that they are lazy, but simply because in their minds - and in their realities - they have better alternatives! Yes, higher wages, better - and more meaningful — employee benefits, better working conditions, and higher degrees of work-life balance will only serve to attract — and retain — better workers. And yet, there is a ceiling as to just what any company - from the Amazon's and Walmart's of the world to your local small business - can and should do to address the ever-being-recalculated "grand bargain" between employers and employees. And yes, we will see companies employ even more automation, more technology and artificial intelligence, and more self-service to produce products and deliver services with less human intervention - and workers. Thus, the time to adapt is now!

\section{REFERENCES}

[1] CDC (U.S. Centers for Disease Control and Prevention) (June 21, 2021). COVID Data Tracker (Online). Available: https://covid.cdc.gov/covid-data-tracker/\#datatracker-home.

[2] WHO (World Health Organization) (June 21, 2021). WHO Coronavirus (COVID-19) Dashboard (Online). Available: https://covid19.who.int.

[3] J. Noh and G. Danuser (February 8, 2021). Estimation of the fraction of COVID-19 infected people in U.S. states and countries worldwide. PLoS ONE (Online), 16(2). Available: https://journals.plos.org/plosone/article?id=10.1371/journal.pone.024 6772 .

[4] J. Watson and C.K. Johnson (March 24, 2021). Brighter outlook for US as vaccinations rise and deaths fall. AP News (Online). Available: https://apnews.com/article/us-vaccination-rise-coronavirus-deathsfall-00fc8be959230a05fafaff6452c2f0d5.

[5] Bureau of Labor Statistics (BLS) (June 10, 2021). 335 Metro Areas Had Over-the-Year Employment Increases in April 2021. TED: The Economics Daily (Online). Available: https://www.bls.gov/opub/ted/2021/335-metro-areas-had-over-theyear-employment-increases-in-april-2021.htm.
[6] P. McGeehan (December 22, 2020). A Million Jobs Lost: A 'Heart Attack' for the N.Y.C. Economy. The New York Times (Online). Available: https://www.nytimes.com/2020/07/07/nyregion/nycunemployment.html.

[7] D. Matthews (April 30, 2021). How the US won the economic recovery. Vox (Online). Available: https://www.vox.com/22348364/united-states-stimulus-covidcoronavirus.

[8] D. Bachman (March 3, 2020). The economic impact of COVID-19 (novel coronavirus). Deloitte Insights (Online). Available: https://www2.deloitte.com/us/en/insights/economy/covid19/economic-impact-covid-19.html.

[9] P. Carlsson-Szlezak, M. Reeves, and P. Swartz (March 3, 2020). What Coronavirus Could Mean for the Global Economy. Harvard Business Review (Online). Available: https://hbr.org/2020/03/what-coronaviruscould-mean-for-the-global-economy.

[10] Bureau of Labor Statistics (BLS) (May 12, 2020). Payroll employment down 20.5 million in April 2020. TED: The Economics Daily (Online). Available: https://www.bls.gov/opub/ted/2020/payroll-employmentdown-20-point-5-million-in-april-2020.htm.

[11] D. Mangan (March 16, 2020). Trump issues 'Coronavirus Guidelines' for next 15 days to slow pandemic. CNBC (Online). Available: https://www.cnbc.com/2020/03/16/trumps-coronavirus-guidelinesfor-next-15-days-to-slow-pandemic.html.

[12] Bureau of Labor Statistics (BLS) (May 13, 2020). Unemployment rate rises to record high 14.7 percent in April 2020. TED: The Economics Daily (Online). Available: https://www.bls.gov/opub/ted/2020/unemployment-rate-rises-torecord-high-14-point-7-percent-in-april-2020.htm.

[13] E. Levitz (2021). The Case for (and Against) Worrying About Inflation. Intelligencer (Online). Available: https://nymag.com/intelligencer/article/inflation-coming-2021-risingprices.html.

[14] Bureau of Labor Statistics (BLS) (May 12, 2021). U-3 was 6.1 percent, U-6 was 10.4 percent, in April 2021. TED: The Economics Daily (Online). Available: https://www.bls.gov/opub/ted/2021/u-3-was-6-1percent-u-6-was-10-4-percent-in-april-2021.htm.

[15] Bureau of Labor Statistics (BLS) (June 10, 2021). News Release Metropolitan Area Employment and Unemployment Summary (Online). Available: https://www.bls.gov/news.release/metro.nr0.htm.

[16] M. White (January 3, 2021). The 10 Largest States by Population Moving.com (Online). Available: https://www.moving.com/tips/the10-largest-states-by-population/.

[17] D.C. Wyld (June 9, 2021). How Companies Should Best Respond to the Worker Shortage. Modern Business (Online). Available: https://medium.com/modern-business/how-companies-should-bestrespond-to-the-worker-shortage-493527184598.

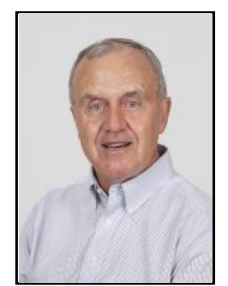

Dr. David C. Wyld received a D.B.A. in Management from the University of Memphis in 1993. Previously, he had earned both an M.B.A. and a B.B.A. from Stephen F. Austin State University in Nacogdoches, Texas in 1985 and 1984, respectively.

He currently serves as the Merritt Professor of Strategic Management at Southeastern Louisiana University. Dr. Wyld is the founder and publisher of both Modern Business Presss (publisher of leading edge journals) and The IDEA Publishers (publishing articles across a wide variety of topics giving both newbie authors and content marketers a platform for their ideas). As a prolific writer himself, he is a regular contributor to respected academic journals and widely-read trade and general interest publications. He has established himself as one of the leading academic experts on the applications of emerging technologies in both the public and private sectors. Dr. Wyld continues to serve as a strategic management consultant, a qualified expert witness, and an invited speaker to a wide variety of trade, corporate, governmental, and academic audiences.

Dr. Wyld has been awarded Southeastern Louisiana University's President's Award for both Excellence in Teaching and Excellence in Research. As a recipient of both awards, he is among a select group of faculties to have been recognized in both roles. 